\title{
The Effect of Supplementation of Gliricidia or Rice Bran on Feed Intake, Digestibility and Liveweight Gain of Kacang Goat Fed Mulato Grass
}

\author{
Marsetyo, Damry and Mustaring \\ Department of Animal Sciences, Tadulako University, Palu 94118, Indonesia
}

\begin{abstract}
A low liveweight gain of of Kacang goats when given grass as single feed indicated that additional feed is required to increase their gowth performance. This study was done to examine the effect of addition of Gliricidia (Gliricidia sepium) leaf or rice bran on feed intake, feed digestibility and liveweight gain of Kacang goat given Mulato (Brachiaria mulato) grass. Twenty four male Kacang goat, approximately $13.4 \pm 0.6 \mathrm{~kg}$ in initial weight and 10 months of age, were housed in individual metabolic pen and allocated to one of three dietary treatments. The experimental design was a completely randomized block design, with three treatments and eight replicates (goats). The treatments were Mulato grass ad libitum (M), Mulato + Gliricidia (1\% weight/d on dry matter basis) (MG), and Mulato + rice bran (1\% weight/d on dry matter basis) (MR). The experiment was run for eight weeks period (two weeks for adaptation and and six weeks for measurement period, respectively). Parameters measured were liveweight gain (LWG), dry matter intake (DMI) and dry matter digestibility (DMD). The result showed that dietary treatment significantly $(P<0.05)$ affected the LWG, DMI and DMD of Kacang goat. Goat given Mulato grass had the lowest LWG, DMI and DMD with value $58 \mathrm{~g} / \mathrm{d}$, 2.77\% weight/d and 57.61\%, respectively. Goat received Mulato + Gliricidia and Mulato + rice bran had a significant higher LWG (73 g/d and 76 g/d, respectively), DMI (3.25\% weight/d and 3.65\% weight/d, respectively) and DMD (62.28\% and 63.19\%, respectively). However, no significant difference $(P>0.05)$ between goat received Mulato + Gliricidia and Mulato + rice bran. In conclusion, this study demonstrated that protein or energy contents of the diet influenced growth, feed intake and digestibility of Kacang goat.
\end{abstract}

Key words: Kacang goat, Mulato grass, Gliricidia and rice bran.

\section{Introduction}

Goat plays great roles in the area of biology and economy in Indonesian farming system, because it is source of animal protein, incomes and organic fertilizer. Besides, goat also provides job, safe deposit (sources of cash in emergency, as insurance for crop harvest failure) and the potential to reduce poverty. At national level, the population of goat increased from time to time. For example in 2009, goat population in Indonesia was 15.82 million head and increased to 18.64 million head in 2014. This leads to the contribution of meat production from goat up to 65.9 thousand tons per year or $2.15 \%$ of total meat production [1]. The data suggest that the contribution

Corresponding author: Marsetyo, professor, research field: ruminant feed technology. of goat meat production is still low and needs to be increased through increasing goat population and productivity.

However, liveweight gain (LWG) of Kacang goat given native grass as single feed is generally low. In previous studies, some reserachers reported that daily LWG of Kacang goat given native grass was 45, 30 and $43 \mathrm{~g} / \mathrm{d}$, respectively [2-4]. This poor growth performances are mainly due to insufficient supply of protein or other nutrients for animals, particularly during dry season [5, 6]. Research conducted by Marsetyo et al. [7] and Poppi et al. [8] reported that crude protein (CP) content of native grass in Central Sulawesi and other part of Indonesia is mainly low, which ranged at 5\%-8\%. Lower of CP content of forages often resulted in the longer retention time of its digesta in the rumen which caused a lower feed 
intake [5]. This suggests that additional feed with high $\mathrm{CP}$ content is required to increase growth performance of Kacang goats. The use of improved grass, such as Mulato (Brachiaria mulato) grass plus supplement feed is one way to improve growth performance of Kacang goats. Many previous studies reported that supplementing basal grass diets with legume forage or concentrate has increased feed intake and diet digestibility by ruminant livestock [7, 9, 10]. Feed supplement improves nitrogen $(\mathrm{N})$ retention by the ruminant, when grass diets that do not meet ruminant energy and $\mathrm{N}$ requirements are fed $[5,7]$.

There are many feed resources in Central Sulawesi that can be used as alternatives to cereal grains for feeding to ruminants, including goat. Gliricidia leaves or rice bran can be used to correct feed deficiency of the goat and is potentially to increase their growth. Gliricidia sepium is one of tree legumes, which is most widely cultivated in Central Sulawesi province. This tree is cultivated with multipurposes, such as for fuelwood, living fence, animal forage, green manure and soil stabilisation. Gliricidia is also rich in CP and can often be used as feed supplement for poor quality forages in the tropics. This legume tree can potentially become the major source of feed for goat during dry season [9].

Rice bran is byproduct of rice, which is in the form of powdery fine and fluffy material. This product contains seeds and kernels together with particle of pericarp, seed coat, aleurone, germ and fine starchy endosperm. The availability of bran is abundant in Indonesia. In this country, an estimated 7.1 million tonnes of rice bran are produced annually [11]. Nutritionally, this feedstuff is rich in protein, fats, mineral and micronutrients, such as vitamin B and trace element that are needed by goats.

While Gliricida and rice bran have long been recognised as goat feed supplement, their use at farmer level are still limited due to lack of knowledge about their nutrition potential. This study was therefore directed to examine the effects of addition of Gliricidia or rice bran on feed intake, digestibility and LWG of Kacang goats given Mulato grass as a basal diet.

\section{Materials and Methods}

\subsection{Site and Time}

The experiment was conducted at the experimental farm, Department of Animal Sciences, Tadulako University, Palu, Central Sulawesi from July to September 2013.

\subsection{Treatments and Experimental Procedures}

Twenty four Kacang goats purchased from local markets, with initial weighing $13 \pm 0.6 \mathrm{~kg}$, were used for the experiment. These animals were ranked and blocked on the basis of their un-fasted live weights. Within blocks, the animals were then randomly allocated to individual metabolism crates pens $(0.5 \mathrm{~m}$ $\times 1.5 \mathrm{~m}$ ) and assigned to one of the dietary treatments tested: Mulato grass ad libitum (M), Mulato grass + Gliricidia (MG) and Mulato grass + rice bran (MR). The Gliricidia or rice bran was offered at a rate of $1 \%$ body weight on dry matter basis. All goats were treated with IVOMEC ( $1 \mathrm{~mL} / 10 \mathrm{~kg}$ of live weight) to eliminate internal and external parasites at the beginning of preliminary period.

Experimental animals were confined in individual pens. The experiment lasted for eight weeks, consisting of two weeks of adaptation period to diets and experimental routines and six weeks of measurement. The experiment employed a completely randomized block design with three treatments and eight replicates (animals) per treatment. The supplements were given once daily at 07:00 h and fed separately to basal diet. Initially, the animals receiving the supplemental treatment were accustomed to the supplement by gradually introducing the supplement over the first $7 \mathrm{~d}$ of the preliminary period. Mulato grasses were obtained from the farm, cut fresh daily and offered to the corresponding animals twice a day at 08:00 and 13:00 h. The grasses were cut to $5-10 \mathrm{~cm}$ in length before feeding. The amounts of basal feed 
offered to the goat daily were set at $10 \%$ more than that basal feed intake of the previous day. Drinking water was provided in bucket placed to each crate for ad libitum intake.

\subsection{Chemical Analyses}

Feed offered, feed refusal and faeces collected during digestibility run were sampled and their representative were ground and analyzed to determine their day matter (DM), organic matter (OM) and ether extract (EE) content [12]. Samples were dried to a constant weight at $60{ }^{\circ} \mathrm{C}$ using oven. Feed offers were also sampled for neutral detergent fibre (NDF) [13] and $\mathrm{N}$ analysis to determine its $\mathrm{CP}$ content, by using the Kjeldahl laboratory method.

\subsection{Statistical Analysis}

Data collected (feed intake, digestibility and growth of goat) were analyzed as a block randomized design using ANOVA in Genstat statistical package [14]. The mean differences between treatments were compared by least significant differences test [15].

\section{Results and Discussion}

The nutritive value of feed given to goat is presented in Table 1. The main difference between Mulato grass, Gliricidia and rice bran is the CP and DM content. The CP content of Gliricidia is more than double of the CP content of Mulato grass (23.7\% vs. $11.3 \% \mathrm{DM})$. In addition, Gliricidia contained the lowest NDF (38.55\% DM) compared with Mulato grass and rice bran. Rice bran showed the highest DM (87.3\%) and EE (6.7\% DM) contents compared with Mulato grass and Gliricidia.

The effect of supplement intake on feed intake is shown in Table 2. Forage intake on DM basis was the lowest $(2.52 \% \mathrm{~W} / \mathrm{d})$ for goats receiving Mulato grass + Gliricidia, compared goat receiving Mulato grass and Mulato grass + rice bran, respectively, but no significant difference $(P>0.05)$ between the last two groups. All goats receiving Gliricidia or rice bran did not consume $100 \%$ of their total allowance. Supplement intake expressed as percentage of liveweight was higher for goats received rice bran (98\%) than Gliricidia (73\%). Although the supplementation increased total DM intake, in fact, supplement resulted in the decline of forage intake that often called as a substitution. In this study, the substitution rates with addition of Gliricidia and rice bran at level of $1 \%$ weight/d on dry matter basis were

Table 1 Nutritive value of feed used in the experiment.

\begin{tabular}{llllll}
\hline Feedstuff & $\begin{array}{l}\text { DM } \\
(\%)\end{array}$ & $\begin{array}{l}\text { OM } \\
(\% \mathrm{DM})\end{array}$ & $\begin{array}{l}\text { CP } \\
(\% \mathrm{DM})\end{array}$ & $\begin{array}{l}\text { NDF } \\
(\% \mathrm{DM})\end{array}$ & $\begin{array}{l}\text { EE } \\
(\% \mathrm{DM})\end{array}$ \\
\hline Mulato grass & 29.8 & 92.1 & 11.3 & 59.1 & 1.6 \\
Gliricidia & 31.7 & 90.8 & 23.7 & 38.5 & 3.0 \\
Rice bran & 87.3 & 93.4 & 10.6 & 45.4 & 6.7 \\
\hline
\end{tabular}

DM: dry matter; OM: organic matter; CP: crude protein; NDF: neutral detergent fibre; EE: ether extract.

Table 2 Feed intake, digestibility and growth of Kacang goat given Mulato grass, Mulato grass + Gliricidia or rice bran.

\begin{tabular}{llll}
\hline Parameter & Mulato grass & Mulato grass + Gliricidia & Mulato grass + rice bran \\
\hline Forage intake (kg DM/d) & $0.42 \pm 0.01$ & $0.38 \pm 0.01$ & $0.39 \pm 0.01$ \\
Forage intake (\% W/d) & $2.77 \pm 0.08^{\mathrm{b}}$ & $2.52 \pm 0.07^{\mathrm{a}}$ & $2.67 \pm 0.09^{\mathrm{b}}$ \\
Supplement intake (kg DM/d) & 0.00 & $0.12 \pm 0.01$ & $0.14 \pm 0.01$ \\
Supplement intake (\% W/d) & 0.00 & $73.00 \pm 2.00$ & $98.00 \pm 1.00$ \\
Total intake (kg DM/d) & $0.42 \pm 0.01^{\mathrm{a}}$ & $0.50 \pm 0.01^{\mathrm{b}}$ & $0.53 \pm 0.01^{\mathrm{b}}$ \\
Total intake (\% W/d) & $2.77 \pm 0.07^{\mathrm{a}}$ & $3.25 \pm 0.05^{\mathrm{b}}$ & $3.65 \pm 0.08^{\mathrm{b}}$ \\
DMD (\%) & $57.61 \pm 1.07^{\mathrm{a}}$ & $62.28 \pm 1.09^{\mathrm{b}}$ & $63.19 \pm 1.12^{\mathrm{b}}$ \\
LWG (g/d) & $58.33 \pm 2.80^{\mathrm{a}}$ & $72.62 \pm 2.01^{\mathrm{b}}$ & $75.79 \pm 0.73^{\mathrm{b}}$ \\
\hline
\end{tabular}

Means with different superscripts in same raw were significantly different $(P<0.05)$. 
$9 \%$ and $4 \%$, respectively. This is only small substitution rate. The reason of this substitution is not clear, but probably because of limited gut fill and increasing intake of metabolisable energy (ME) due to supplemental feed. Goats received Gliricidia had higher basal feed intake depression compared goats received rice bran. Both Gliricidia and Mulato grass were bulky materials, which could limit capacity in reticulorumen. The result of this study is in agreement with the results in previous study [7], which suggests that physical condition of supplement can potentially result in the decrease in forage intake due to physical limitation.

The effect of supplement intake on dry matter intake (DMD) and daily LWG are shown in Table 2. In both parameters, the greatest values were achieved by goat received Mulato grass + Gliricidia and Mulato grass + rice bran, and no significant differences $(P>$ 0.05 ) between two treatments (Table 2). The values of DMD for Mulato grass + Gliricidia and Mulato grass + rice bran treated goats were $4.67 \%$ and $5.58 \%$ higher respectively than Mulato grass treated goats. This study demonstrated that addition extra $\mathrm{N}$ to goat given Mulato grass + Gliricidia could stimulate feed intake and digestibility. The stimulation of total intake and digestibility of goats supplemented with Gliricidia or rice bran could be due to increased N intake, and this is also supported by earlier studies [5, 7]. Assuming that $\mathrm{N}$ is one of the major limiting nutrients (along with minerals, particularly sulphur and soluble carbohydrate) in forage, a significant increase in intake and digestibility could have been expected, when supplementary $\mathrm{N}$ was provided. Carbohydrate supplementation in addition, supplies substrates for microbial activity in the rumen. The reason for the highest responses in total intake, digestibility for calves received rice bran could be due to addition of extra $\mathrm{N}$ and carbohydrate from feed component, such as rice bran. These results suggest that addition of energy and protein to the basal diet dictated feed intake and digestibility of Kacang goat.
Addition of Glricidia or rice bran to Mulato grass significantly increased $(P<0.05)$ daily LWG of Kacang goat, although no significant differences $(P>$ 0.05 ) between them (Table 2). Goat received Mulato grass had the lowest daily LWG (58.33 g/d). The main constrainsts leading to these lower goat performances given Mulato grass only are probably from lower supply of CP or other nutrients for animal, which resulted in the low rate of productivity. Many previous studies indicated that CP content of feed influence significantly feed intake and digestibility and retention time of digesta in the rumen $[4,5,16]$. The total feed intake and digestibility of goats received Mulato grass were significantly lower $(P<0.05)$ than goats received Mulato grass + Gliricidia and Mulato grass + rice bran. This finding is in agreement with earlier finding [5], which found a longer retention time of digesta in the rumen when the CP content of feed is low. The current study demonstrated that the addition of simple supplements, such as Gliricidia or rice bran to Mulato grass can result in higher daily LWG than goats given Mulato grass only. The current data of LWG of goat offered Mulato grass as single feed is relatively closed to the finding of Marsetyo [4]. In the previous study, this author reported that daily LWG of Kacang goats given Mulato grass as single feed was $53.50 \mathrm{~g} / \mathrm{d}$, which is much higher than goat given native grass $(28.11 \mathrm{~g} / \mathrm{d})$. Both studies used similar materials with similar chemical contents, so it is no surprising for the close growth rate data.

\section{Conclusions}

Both Gliricidia and rice bran are potentially used as goat feed supplement, due to their nutritional content and availabilty. The addition protein from Gliricidia and rice bran can stimulate feed intake, feed digestibility and growth rates of young Kacang goat given Mulato grass. It is recommended that both supplements can be used widely as additional feed to increase the growth performance of Kacang goat given low quality forages. 


\section{Acknowledgments}

The authors wish to show their appreciation to Directorate of Higher Education (DIKTI) for providing the fund for this study through the Penelitian Unggulan Perguruan Tinggi. They are also grateful to Rulisman, who helped in collecting goats, and the undergraduate students I Wayan Dharma Yadi and Reza Faizal at the Department of Animal Science, Tadulako University, who assisted with this research as part of their honours program.

\section{References}

[1] Livestock and Animal Health Statistic (LAHS). 2015. "The Directorate General of Livestock and Animal Health Services, Ministry of Agriculture, Jakarta.” Accessed April 20, 2016. https://drive.google.com/file/d/0B58Jq7b22RQWN09mV UJjYnhFd1E/view?pref=2\&pli=1.

[2] Liwa, A. M. 1996. "The Qualitative and Quantitative Parameters of Kacang Goats and Crossbreed between Kacang Goats and Ettawah Goats.” Bul. Ilmu Peternakan dan Perikanan 11: 45-56.

[3] Garantjang, S. 2004. "Growth of Kacang Kids at Various Age under Traditional Management System.” J. Sain. and Teknol. 4: 40-5. (in Indonesian)

[4] Marsetyo. 2014. "New Grasses (Brachiaria mulato and Paspalum atratum) to Increase Growth Performances of Kacang Goats Raised by Smallholder Farmers.” In Proceedings of the 16th Asian-Australasian Associations of Animal Production Societies, 437-40.

[5] Panjaitan, T., Quigley, S. P., McLennan, S. R., Swain, T., and Poppi, D. P. 2010. "Intake, Retention Time in the Rumen and Microbial Protein Production of Bos indicus Steers Consuming Grass Varying in Crude Protein Content.” Anim. Prod. Sci. 50 (6): 444-8.

[6] Sodiq, A., Priyono, A., and Tawfik, E. S. 2011. "Assessment of the Kid Production Traits of Kacang
Goat under Smallholders Production System.” J. Anim. Prod. 12 (2): 111-7.

[7] Marsetyo, Damry, Quigley, S. P., McLennan, S. R., and Poppi, D. P. 2012. "Live Weight Gain and Feed Intake of Early Weaned Bali Cattle Fed a Range of Diets in Central Sulawesi, Indonesia.” Anim. Prod. Sci. 52: 167-72.

[8] Poppi, D. P., Budisantoso, E., Dahlanuddin, Marsetyo, Pamungkas, D., Panjaitan, T., Priyanti, A., McLennan, S. R., and Quigley, S. P. 2009. Final Report: Strategies to Increase Weaned Bali Calves (Project: LPS/2004/03). Australian Centre for International Agricultural Research, Canberra.

[9] Simons, A. J., and Stewart, J. L. 1994. “Gliricidia sepium, a Multipurpose Forage Tree Legume.” In Forage Tree Legumes in Tropical Agriculture, edited by Gutteridge R. C., and Shelton, H. M. Wallingford, UK: CAB International, 30-48.

[10] Ngongoni, N. T., Mwale, M., Mapiye, C., Moyo, M. T., Hamudikuwanda, H., and Titterton, M. 2008. "Research Note: Inclusion of Lablab in Maize and Sorghum Silages Improves Sheep Performance.” Trop. Grassland 42: 188-92.

[11] Badan Pusat Statistik (BPS). 2015. "The Statistic of Indonesia.” Badan Pusat Statistic, Jakarta. Accessed May 2, 2016. https://www.bps.go.id/index.php/brs/1272.

[12] Association of Official Analytical Chemists (AOAC). 1990. Official Methods of Analysis, 15th ed.. Arlington, Virginia: AOAC.

[13] Goering, H. K., and Van Soest, P. J. 1970. Forage Fibre Analysis: Apparatus, Reagents, Procedures and Some Applications. Washington: Agricultural Research Service.

[14] GenStat. 2010. Sofware for Bioscience, 12th ed.. Oxford: VSN-International, Ltd..

[15] Steel, R. G. D., and Torrie, J. H. 1980. Principles and Procedures of Statistics: A Biometrical Approach, 2nd ed.. New York: McGraw-Hill Book Company.

[16] Riaz, M. Q., Südekum, K. H., Clauss, M., and Jayanegara, A. 2014. "Voluntary Feed Intake and Digestibility of Four Domestic Ruminant Species as Influenced by Dietary Constituents: A Meta-Analysis.” Livestock Science 162: 76-85. 